\title{
Differences of Salivary Total Protein Levels in Plaque Induced Gingivitis and Healthy Patients in Periodontology Clinic of the Faculty of Dentistry USU Medan
}

\author{
Aini Hariyani Nasution \\ Department of Periodontics \\ Faculty of Dentistry, Universitas Sumatera Utara \\ Medan, Indonesia
}

\author{
Anushkaa Ravi Balan \\ Student \\ Faculty of Dentistry, Universitas Sumatera Utara \\ Medan, Indonesia
}

\begin{abstract}
Gingivitis is an inflammation of the gingiva due to an accumulation of bacterial plaque that can cause periodontal structural damage. In general, to diagnose gingivitis involves clinical measurements and radiographic assessment which are often poorly tolerated by the patients and are also subjected to measurement errors. Some researchers have found that saliva provides an easily available, non-invasive diagnostic medium for a rapidly widening range of diseases and clinical situations saliva. The aim of this study is to determine the difference of salivary total protein levels in plaque induced gingivitis and healthy patients. This bivariate analytic study is a non-experimental study, with a cross sectional design. 30 samples of saliva were taken by purposive sampling method and divided into saliva of patients suffering from plaque induced gingivitis and saliva of healthy patients, as control. Gingivitis was measured using Papilla Bleeding Index (PBI) while the total protein level of saliva was measured using the Bradford Assay method. The results of this study indicated that there was a significant difference $(p<0.05)$ in salivary total protein levels between the plaque induced gingivitis patients and healthy patients. Plaque induced gingivitis patients had high protein content with a mean value of 0.360 while the mean value of healthy patient was 0.108 . Based on the results of the study it is concluded that there was an increase in protein level in saliva in plaque induced gingivitis patients.
\end{abstract}

Keyword -plaque induced gingivitis, salivary total protein, healthy patients

\section{INTRODUCTION}

"Peri" means around and "odontal" refers to the teeth. Periodontal disease is a form of bacterial inflammation in the structures around the teeth, including gingiva, cementum, periodontal ligament and alveolar bone [1]. There are two forms of periodontal disease namely periodontitis and gingivitis [2,3]. Gingivitis is an inflammation of the gingiva due to bacterial plaque accumulation [4]. The prevalence of gingivitis in Indonesia ranks second, reaching $96.58 \%$ [5]. Generally, the way to diagnose periodontal disease involves clinical examination and radiographic assessment that is often difficult for the patient to tolerate and also likely to have errors in measurement.
Therefore, currently there are ongoing studies to evaluate the possibility of compounds in oral fluid which allows assessing the presence and severity of periodontal disease [6]. Much of the research has focused on the analysis of gingival sulcus fluid which is a serum transudate of the gingival blood vessels located close to the surface of the dentogingival junction epithelium [7]. The analysis of gingival sulcus fluid shows the activity of the disease in the dental region individually rather than the entire oral cavity that complicates the interpretation [8]. There is also a technical problem in using gingival sulcus fluid where the collection of gingival sulcus fluid is complicated, requires skill and its time consuming. In addition, measurement of the amount of gingival sulcus fluid and analytical concentration is difficult because of the amount of gingival sulcus obtained are significantly small.

Saliva is a colourless liquid, consistency like mucus, and is the result of glandular secretions that continuously moisten the teeth and oral mucosa [9]. Salivary components, which are soluble, secreted by salivary glands, can be distinguished into organic and inorganic. Organic salivary components are composed of proteins including alpha-amylase, lysozyme, calicrein, lactoperosidase and mucine enzymes [10-12]. Inorganic components comprise sodium, potassium, calcium, magnesium, phosphate, bicarbonate, chloride, nitrate and potassium $[4,10,12]$. Some researchers have found that saliva is a non-invasive diagnostic medium for various illnesses and clinical conditions [13]. Saliva is an easily collected oral solution and does not require specialized equipment or techniques [14]. Saliva compositions are similar to plasma; therefore saliva has been widely used as a sample in the examination of biomarkers (measurement of substance as an indication of a phenomenon) for pathological conditions in the oral cavity [15].

Protein is an amino acid source consisting of elements C, H, O and N [16,17]. Studies show the presence of proteins as cellular stress responses, including heat shock responses, endoplasmic reticulum 
stress responses, and interfering DNA damage responses and regulating intermediate signals involved in activation of the innate and adaptive immune response $[18,19]$.

The study conducted in Brazil by Anne et al, showed elevated levels of glucose, protein, albumin, urea and amylase in saliva of gingivitis and periodontitis patients [20]. Based on the Henskens et al study, the group with periodontal disease showed a 1.8 increase in total protein content compared with the healthy group [13]. According to Mulki et al, there is an increase in total protein content and amylase in saliva of patients with periodontal disease [13]. Kejriwal et al reported an increase in salivary mucin, amylase and total protein levels in gingivitis patients [6]. However, there is also research showing that there is a decrease in C- reactive (CRP) protein in patients with periodontal disease, among others, studies conducted by Aurer et al. [21].

This difference of opinion makes the authors interested in doing this study which has still not been studied in Indonesia to determine the difference of total salivary protein level in plaque induced gingivitis and healthy patients.

\section{MATERIALS AND METHODS}

This is a non-experimental research with cross sectional design. It involves a total of 30 samples that were chosen using purposive sampling method which was divided into plaque induced gingivitis (test group) and healthy periodontium (control group). The study was conducted in Periodontology Clinic of the Faculty of Dentistry USU Medan and Biochemistry Laboratory of the Faculty of Medicine USU, Medan. Gingivitis was measured using Papilla Bleeding Index (PBI) while the total protein level of saliva was measured using the Bradford Assay method.

Firstly, the subjects of study were determined according to the inclusion criteria (in the test group, subjects with PBI more than 30) and exclusion criteria (subjects with history of any systemic diseases or conditions, history of any salivary gland diseases, fever). Subjects were given explanation about the purpose, benefit and research procedure that will be done and ask their willingness to participate in research by obtaining written informed consent. Saliva was collected using unstimulated draining method. Subjects are told to drain their saliva out of their mouth into a container as much as $3 \mathrm{ml}$. The sample was then transferred into a Falcon tube and was immediately labelled accordingly.

Saliva samples were directly inserted into the cool box and were brought to the Biochemistry Laboratory of the Faculty of Medicine USU, Medan. Samples were stored at $-20^{\circ} \mathrm{C}$ until all the samples were collected for analyse. At the time of the analysis, the sample was centrifuged at $3000 \mathrm{rpm}$ and the supernatant was extracted. The salivary total protein level was determined using the Bradford method which was performed on the basis of binding of the Coomassie
Blue G-250 dye to the protein. (Detection limit: 25 $\mu \mathrm{g} / \mathrm{mL}$, Linearity Limit: $2.5 \mathrm{mg} / \mathrm{mL}$ ). $200 \mu \mathrm{l}$ of the Bradford reagent was added to the $10 \mu \mathrm{l}$ standard solution and the sample in Falcon tube using multichannel pipette. Then, the Falcon tube was spinned down using vortex. After that, the samples were then incubated for 10 minutes at room temperature. Later, the absorbance was measured using a spectrophotometer with a wavelength of $595 \mathrm{~nm}$. The protein concentration was determined according to the protocols written on the packaging. (Ksampel $\mathrm{x} 7 \mathrm{~g} / \mathrm{dL}$ /Kstandard). The data of each examination was done by Shapiro-Wilk normality test to see the distribution of data and Mann-Whitney test was done to see the difference of salivary total salivary protein level in plaque induced gingivitis and healthy patients.

\section{RESULTS}

TABLE I. THE CONCENTRATION OF SALIVARY TOTAL PROTEIN LEVEL IN PLAQUE INDUCED GINGIVITIS AND HEALTHY PATIENTS

\begin{tabular}{|c|c|c|}
\hline Sample & Plaque Induced Gingivitis (g/dL) & Healthy $(\mathbf{g} / \mathbf{d L})$ \\
\hline 1 & 0.562 & 0.078 \\
\hline 2 & 0.970 & 0.058 \\
\hline 3 & 0.213 & 0.039 \\
\hline 4 & 0.330 & 0.136 \\
\hline 5 & 0.213 & 0.039 \\
\hline 6 & 0.194 & 0.019 \\
\hline 7 & 0.233 & 0.175 \\
\hline 8 & 0.427 & 0.097 \\
\hline 9 & 0.465 & 0.175 \\
\hline 10 & 0.349 & 0.136 \\
\hline 11 & 0.213 & 0.155 \\
\hline 12 & 0.271 & 0.039 \\
\hline 13 & 0.330 & 0.039 \\
\hline 14 & 0.388 & 0.194 \\
\hline 15 & 0.252 & 0.252 \\
\hline Mean & 0.361 & 0.109 \\
\hline & & \\
\hline
\end{tabular}

TABLE II. THE RESULT OF DIFFERENCE OF SALIVARY TOTAL PROTEIN LEVELS IN PLAQUE INDUCED GINGIVITIS AND HEALTHY PATIENTS

\begin{tabular}{|c|c|c|}
\hline Variable & $\begin{array}{c}\text { Mean of Salivary Total } \\
\text { Protein Level (g/dl) }\end{array}$ & $\mathbf{p}$ \\
\hline $\begin{array}{c}\text { Plaque induced } \\
\text { gingivitis }\end{array}$ & 0.361 & $0.000^{*}$ \\
\hline Healthy & 0.109 & \\
\hline
\end{tabular}

\section{DISCUSSION}

The average mean of salivary total protein level in plaque induced gingivitis patients was 0.361 and healthy patient showed an average of 0.109 . The average mean of salivary total protein level in plaque induced gingivitis patients showed higher results than healthy patients with a significant value of 0.000 ( $p$ $<0.05$ ). This proves that there is a significant difference between salivary total protein levels in plaque induced gingivitis and healthy patients.

The results of this study are in line with a study conducted by Henskens et al who said that the group with gingivitis disease showed an increase in total protein levels by 1.8 times compared with the control group (healthy) [13]. The study by Kejriwal et al was also in line with this study where the total salivary protein content of the gingivitis group had a mean of 
3.8 and the healthy group was 2.9 . The results showed an increase in total protein levels in the gingivitis group. According to Kejriwal et al, the increased total protein levels in saliva can be caused by an inflammatory process that activates the sympathetic system to increase the synthesis and secretion of some proteins thereby increasing the protective potential of saliva against the disease [6].

Researcher Anne stated that leakage of protein proteins occurs as a tissue inflammatory response that results in an increase in total protein levels in saliva. In Anne's study, the results showed elevated levels of total protein in salivary gingivitis patients [20]. Research conducted by Mulki Shaila et al showed a high total protein content in the saliva of gingivitis patients. High total protein levels in salivary gingivitis patients are most likely caused by high levels of synthesis and secretion in the mouth. Periodontal microbes due to gingivitis trigger an inflammatory response and lead to leakage of protein plasma. Therefore, the salivary glands actively synthesize and salivate saliva with high protein components [13]. Another study conducted by Aurer A et al. showed that there was a decrease in the levels of C-reactive protein (CRP) in patients with periodontal disease [21]. In this study, total protein levels involving all types of proteins in the oral cavity including CRP were observed and the results showed a significant increase in total protein levels in salivary gingivitis groups.

The results of Aurer A are in contrast to the results of this study. Protein in saliva is involved in many biological processes including cellular support, tissue strain and flexibility, immune response and also in enzymatic reactions. These functions vary according to the type of molecule. Therefore, the total protein content in saliva may be affected by several factors. The results of these different studies may be due to the influence of the subject's diet, the presence of hormones, psychiatric disorders, toothbrushing and exercise [20]. Although many researchers evaluate protein levels without nutritional habits, this may be recommended for further research. Because determination of total protein content can be used as an alternative diagnostic tool, more research needs to be done.

As a conclusion, based on the result of the research, there is difference of salivary total protein level in plaque induced gingivitis and healthy patients. This was proved by obtaining the results of studies showing that the salivary total protein level of plaque-induced gingivitis was higher than healthy periodontium.

\section{ACKNOWLEDGMENT}

The authors would like to give special thanks to Periodontology Clinic, Faculty of Dentistry, Universitas Sumatera Utara and Biochemistry Laboratory of the Faculty of Medicine.

\section{REFERENCES}

[1] A.G. Soulissa, "Hubungan kehamilan dan penyakit periodontal," Jurnal PDGI, vol. 63, pp. 71-7, 2014.

[2] K. Wangsarahardja, "Penyakit periodontal sebagai faktor risiko penyakit jantung coroner," Jurnal Universa Medicina, vol. 24(3), pp. 136-144, 2005.

[3] Z.F. Ramadhani, D.K. Tri Putri, Cholil, "Prevalensi penyakit periodontal pada perokok di lingkungan Batalyon Infanteri 621/Manuntung Barabai Hulu Sungai Tengah,” Dentino Jurnal Kedokteran Gigi, vol. 2(2), pp. 115-119, 2014.

[4] M.G. Newman, H.H. Takei, P.R. Klokkevold, F.A. Carranza, Clinical periodontology, $11^{\text {th }}$ ed., Singapore: Elsevier, 2012, pp. 34-64, 66- 96.

[5] A.M. Hamudeng, I. Bakri, "Prevalensi gingivitis terhadap kebiasaan mengunyah satu sisi pada anak usia 6-12 tahun," Makassar Dent. J., vol. 5(3), pp. 76-81, 2016.

[6] S. Kejriwal, R. Bhandary, B. Thomas, S. Kumari, "Estimation of Levels of Salivary Mucin, Amylase and Total Protein in Gingivitis and Chronic Periodontitis Patients," Journal of Clinical and Diagnostic Research, vol. 8(10), pp. 56-60, 2014.

[7] J.J. Taylor, "Protein biomarkers of periodontitis in saliva," Hindawi Publishing Corporation ISRN Inflammation, 2014, pp. $1-18$

[8] B.G. Loos, S. Tjoa, "Host-derived diagnostic markers for periodontitis: do they exist in gingival crevice fluid?" Periodontology, vol. 39, pp. 53-72, 2005.

[9] P.D.V.D. Almeida, A.M.T. Gregio, M.A.N. Machado, A.A.S.D Lima, L.R. Azevedo, "Saliva composition and functions," Journal of Contemporary Dental Practice, vol. 9(3), pp. 1-11, 2008.

[10] D.B. Ferguson, "Oral Bioscience," Authors online, pp. 117-150, 2006.

[11] Greenberg, Glick, Ship. Burket's oral medicine. $11^{\text {th }}$ ed., 2008, pp. 190-3.

[12] R.K. Marya, C.M. Marya, Textbook of Physiology for Dental Students, $2^{\text {nd }}$ ed., New Delhi: CBS, pp. 51-52, 381-383.

[13] S. Mulki, P. Prakash, S. Pushparaj, "Salivary protein concentration, flow rate, buffer capacity and $\mathrm{pH}$ estimation: A comparative study among young and elderly subjects, both normal and with gingivitis and periodontitis," Journal of Indian Society of Periodontology, vol.17(1), pp. 42-46, 2013.

[14] D.M. Rocha, E.G. Zenobio, T. Van Dyke, K.S. Silva, F.O Costa, R.V. Soares, "Differential expression of salivary glycoproteins in aggressive and chronic periodontitis," J. Appl. Oral Sci., vol. 20(2), pp. 180-185, 2012.

[15] B. Zappacosta, Clinical biochemistry, Canada: Elsevier, 2007, pp. 661-665.

[16] A.S. Katili, Struktur dan fungsi protein kolagen,” Jurnal Pelangi Ilmu, vol 2(5), 2009.

[17] F.M. Diana, "Fungsi dan metabolism protein dalam tubuh manusia," Maj. Ked. Gigi Fakultas Kedokteran Gigi Universitas Airlangga, vol. 36(1), pp.74, 2003.

[18] S. Akira, K. Takeda, T. Kaisho, "Toll-like receptors: critical proteins linking innate and acquired immunity," Nat. Immunol, vol. 2, pp. 675-680, 2001.

[19] P.A. Vibhakar, S.R. Patankar, M.R. Yadav, P.A. Vibbhakar, "Salivary total protein levels and their correlation to dental caries," International Journal of Oral \& Maxillofacial Pathology, vol. 4(3), pp. 13-16, 2013.

[20] A.A. Hernandez-Castaneda, G.C. Aranzazu-Moya, G.M. Mora, D.D.P. Queluz, "Chemical salivary composition and its relationship with periodontal diseases and dental calculus," Braz. J. Oral Sci., vol. 14(2), pp. 169-165, 2015.

[21] A. Aurer, K Jorgić-Srdjak, D. Plančak, A. Stavljenić-Rukavina, J. Aurer-Koželjm, "Proinflammatory factors in saliva as possible markers for periodontal disease," Collegium Antropologicum, vol. 29(2), pp. 435-439, 2005. 